\title{
THE RÔLE OF ZINC IN PROMOTING THE OPALESCENCE AND COLD PRECIPITATION OF BOAR SEMINAL PLASMA
}

\section{FURTHER OBSERVATIONS ON THE NATURE OF THE COLD-OPALESCENCE PHENOMENON}

\author{
T. K. ROBERTS,* J. G. BOURSNELL, S. E. WINSOR AND \\ E. A. MUSTILL
}

A.R.C. Unit of Reproductive Physiology and Biochemistry, Cambridge $\dagger$

(Received 13th March 1974)

\begin{abstract}
Summary. The temperature-dependent opalescence caused by the presence of a zinc-precipitable protein (ZPP) in boar seminal plasma has been shown to be $\mathrm{pH}$-dependent.

The considerable $\mathrm{pH}$ increase to which boar seminal plasma is subject on exposure to air is attributed to loss of $\mathrm{CO}_{2}$ from a system with a notable paucity of titratable groups in the physiological range $\mathrm{pH} 7$ to 9 . This markedly affects the temperature-dependent opalescence.

The ZPP has been purified and the temperature-dependent opalescence of this material can be demonstrated only within a narrow range of zinc concentration in the absence of other possible ligands present in whole seminal plasma.
\end{abstract}

\section{INTRODUGTION}

In previous papers (Boursnell \& Roberts, 1974; Roberts, Boursnell \& Brown, 1974), investigations into two opalescence phenomena occurring in boar seminal plasma have been reported. Much of the opalescence at normal temperatures has been shown to be due to specific precipitation of a basic protein by the zinc naturally occurring in the seminal plasma. This zincprecipitable protein (ZPP) was shown to be closely similar to, if not identical with, the seminal haemagglutinin described earlier (Boursnell \& Coombs, 1966; Boursnell, 1967).

The second opalescence phenomenon, also zinc-dependent, is an increase seen when seminal plasma is cooled to temperatures below about $12^{\circ} \mathrm{C}$. This has been termed cold opalescence. Preliminary studies (Roberts et al., 1974) suggested the possibility of the presence of a temperature-sensitive substance, separate from ZPP, in seminal plasma. Further investigations,

\footnotetext{
* Present address: Department of Biological Sciences, University of Newcastle, Newcastle, New South Wales 2308, Australia.

† Postal address: Animal Research Station, 307 Huntingdon Road, Cambridge GB3 0JQ.
} 
reported in this paper, have failed to show the presence of such a temperaturesensitive substance; cold opalescence seemingly can be attributed to ZPP and to critical zinc and hydrogen ion concentrations and possibly also to the effect of citrate combination with seminal plasma proteins as suggested by Roberts et al. (1974).

Investigations described in the two earlier papers on zinc opalescence had presented other problems which required solution before progress could be made. Two of these, the effect of $\mathrm{pH}$ on the opalescence system and the degree of sensitivity of seminal plasma to $\mathrm{pH}$ changes on standing, are largely solved in this paper.

\section{Collection of samples}

\section{MATERIALS AND METHODS}

Seminal plasma was prepared from fresh semen collected from boars housed at the Animal Research Station. The whole semen was filtered through a nylon sieve to remove the gel. Centrifugation $(12,000 \mathrm{~g})$ at $15^{\circ} \mathrm{C}$ removed the spermatozoa from the supernatant seminal plasma, which was used fresh or stored immediately at $-25^{\circ} \mathrm{C}$.

Pig blood plasma was obtained from fresh citrated blood by centrifugation as above. Samples were dialysed before use as described.

\section{Nitrogen determinations}

A micro-Kjeldahl method was employed and the ammonia was determined as described by Boursnell, Hartree \& Briggs (1970).

\section{pH determinations}

These were carried out on a Pye-Unicam (Cambridge) model $292 \mathrm{pH}$ meter fitted with a 401-M5 Ingold glass electrode, with adjustment for $4^{\circ} \mathrm{C}$ measurement as necessary.

\section{Dialysis}

Visking cellophane tubing (Scientific Instrument Centre, London) was used.

\section{Gel-filtration}

This was carried out as described by Roberts et al. (1974), using a column $(2.5 \times 30 \mathrm{~cm})$ of Sephadex G-200 (Pharmacia, Great Britain Ltd, London) and a $\mathrm{pH} 4, \mathrm{I}=0.3$ acetate buffer (Miller \& Golder, 1950).

\section{Ion-exchange chromatography}

Columns of CM-52 (Whatman Biochemicals Ltd, Maidstone, Kent) carboxymethyl cellulose in a 2 mM-EDTA, $20 \mathrm{~mm}$-tris buffer, $\mathrm{pH} 8.5$, were prepared and monitored at $280 \mathrm{~nm}$ as described by Roberts et al. (1974). Elution was carried out using a linear $\mathrm{NaCl}$ gradient in this buffer. In most cases, the gradient used was in the range 100 to $500 \mathrm{~mm}-\mathrm{NaCl}$.

\section{Buffering capacity of native and dialysed seminal plasma and porcine blood plasma}

Seminal plasma samples $(5 \mathrm{ml})$ were titrated to $\mathrm{pH} 3.5$ with $0.1 \mathrm{M}-\mathrm{HCl}$ at 
room temperature with gentle stirring. The $\mathrm{pH}$ was measured after each addition of $0.2 \mathrm{ml}$. An identical sample was also titrated with $0.1 \mathrm{M}-\mathrm{NaOH}$ to $\mathrm{pH}$ 11. Similar titrations were carried out on aliquots of the same seminal plasma dialysed, with two changes, at $4^{\circ} \mathrm{C}$ against $0 \cdot 2 \mathrm{M}-\mathrm{NaCl}$ adjusted to $\mathrm{pH} 7$ with minute amounts of added tris buffer. Tests showed that the amount of tris needed contributed an almost immeasurable increase in the titre between $\mathrm{pH}$ 7 and 9. Graphs of the titrations versus $\mathrm{pH}$ were plotted on a basis of mequiv. titrant/100 mg N (Herriott, Anson \& Northrop, 1947).

\section{Detection of zinc-precipitable protein}

Aliquots for testing were adjusted to a final zinc concentration of $5 \mathrm{~mm}$ using either $50 \mathrm{~mm}$ - or $500 \mathrm{~mm}$-zinc acetate, and brought to $\mathrm{pH} 8$ with tris. The presence of ZPP was shown by the production at room temperature of a white precipitate detected visually or spectrophotometrically at $450 \mathrm{~nm}$ (SP 800 or SP 500, Pye-Unicam Ltd, Cambridge).

\section{Determination of cold opalescence}

Samples (seminal plasma, solutions of zinc-induced precipitate from seminal plasma, or purified ZPP) were treated with $50 \mathrm{~mm}$ - or $500 \mathrm{~mm}$-zinc acetate to give the required zinc concentrations and the $\mathrm{pH}$ was subsequently adjusted to the desired level by additions of $0.1 \mathrm{M}-\mathrm{HCl}, 0.1 \mathrm{M}-\mathrm{NaOH}$ or $1.0 \mathrm{M}$-tris buffer. In some cases, $\mathrm{NaCl}$ was added to a concentration of $0.3 \mathrm{M}$. Opalescence values of 3-ml aliquots of the treated solutions were measured in 1-cm cuvettes as absorbancies at $450 \mathrm{~nm}$ (Boursnell \& Roberts, 1974) either on different samples after $2 \mathrm{hr}$ at room temperature or at $4^{\circ} \mathrm{C}$, or on the same sample exposed to these temperatures for $2 \mathrm{hr}$ each sequentially. The cold opalescence values recorded are mean differences between replicate samples measured at $4^{\circ} \mathrm{C}$ and at room temperature. In some cases, as stated, the cuvettes were covered throughout the experiment with glass lids.

\section{Preparation of zinc-precipitable material from whole seminal plasma}

This was routinely prepared either at $37^{\circ} \mathrm{C}$, room temperature or $4^{\circ} \mathrm{C}$ by addition of 500 mM-zinc acetate solution to stirred 100-ml samples of whole pooled seminal plasma giving a concentration of $5 \mathrm{~mm}$ with subsequent adjustment to $\mathrm{pH} 8$ with $500 \mathrm{~mm}$-tris buffer. After $2 \mathrm{hr}$, the precipitate was centrifuged $(10,000 \mathrm{~g}$ for $20 \mathrm{~min})$ at approximately the relevant temperature, dissolved in $50 \mathrm{ml} 100 \mathrm{~mm}$-EDTA buffer ( $\mathrm{pH} \mathrm{5}$ ) and dialysed against either (a) $20 \mathrm{~mm}$-tris, 2 mm-EDTA, $300 \mathrm{~mm}-\mathrm{NaCl}, \mathrm{pH} 8$, buffer for opalescence studies or (b) 20 mM-tris, 2 mM-EDTA, $100 \mathrm{~mm}-\mathrm{NaCl}$, $\mathrm{pH} 8 \cdot 5$, buffer for ion-exchange chromatography or (c) acetate buffer, $\mathrm{I}=0 \cdot 3, \mathrm{pH} 4$, for gel filtration.

\section{Preparation of purified zinc-precipitable protein}

The zinc precipitate obtained from whole seminal plasma as described above was subjected to four successive fractionations on CM-cellulose. In each case, the sample applied to the second, third and fourth columns was obtained from the fractions of the preceding column which had been shown to contain ZPP. The fractions from the fourth column were pooled according to the protein 
elution profile and tested both for precipitation by zinc and haemagglutinating activity.

\section{Haemagglutinin titre}

Titrations were carried out as described by Boursnell (1967) by doubling dilutions using disposable haemagglutination trays (Staynetray A, Stayne Laboratories, Bishop Auckland, Co. Durham).

\section{RESULTS}

The effect of $p H$, exposure to air and freezing on opalescence values of boar seminal plasma at room temperature and $4^{\circ} \mathrm{C}$

Experiments with many seminal plasma samples were carried out to correlate room temperature and opalescence values at $4^{\circ} \mathrm{C}$ with $\mathrm{pH}$ values between 6 and 9 , obtained by additions of $\mu \mathrm{l}$ quantities of either $0.1 \mathrm{M}-\mathrm{HCl}$ or $0.1 \mathrm{~m}-\mathrm{NaOH}$. Results of typical experiments, each carried out in triplicate, are shown in Text-fig. 1. These samples all showed a maximum response at $\mathrm{pH} 8 \cdot 0$ to $8 \cdot 5$.

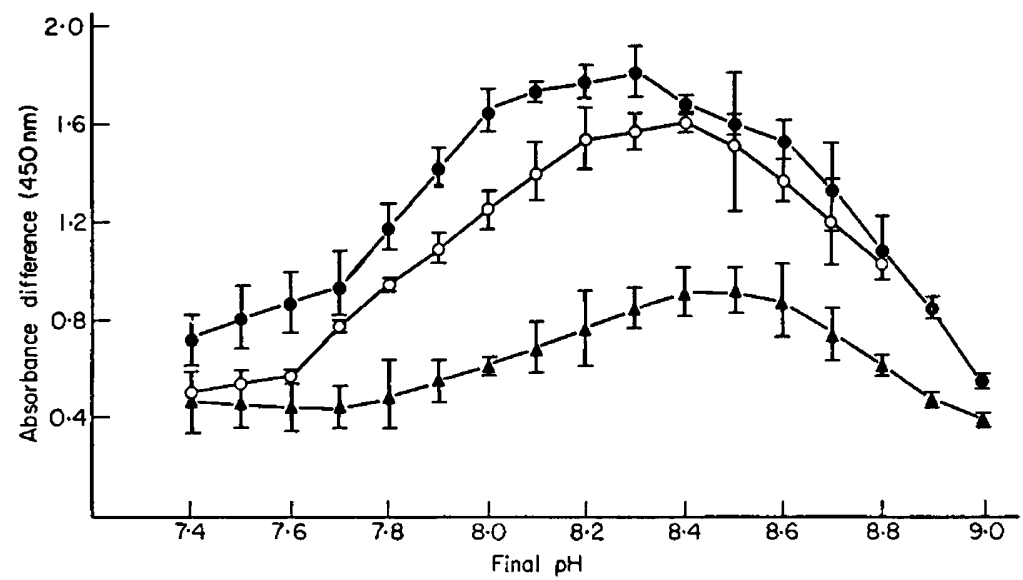

TEXT-FIG. 1. Cold-opalescence values (difference between those at $4^{\circ} \mathrm{C}$ and those at room temperature) measured in covered cuvettes of samples of fresh boar seminal plasma adjusted to various $\mathrm{pH}$ values. Vertical bars represent S.D. values.

If open vessels were used, difficulties were encountered in stabilizing the marked changes of $\mathrm{pH}$ which often occurred, sometimes as much as $1.0 \mathrm{pH}$ unit. Only partial stabilization was achieved when $10 \mathrm{~mm}$-tris and collidine buffers were employed. The $\mathrm{pH}$ and opalescence values of the seminal plasma samples were measured in covered cuvettes and considerable stabilization was conferred in this way.

Experiments upon the effect of rapid freezing to $-25^{\circ} \mathrm{C}$, followed by thawing, carried out in the covered cuvettes showed only marginal changes in the $\mathrm{pH}$ and opalescence values (room temperature and $4^{\circ} \mathrm{C}$ ) of the control seminal plasma, also in covered cuvettes. The same operation in open vessels gave pronounced changes in the opalescence at $4^{\circ} \mathrm{C}$, sometimes reducing this value to about one-third of the control seminal plasma value. 
Table 1. Buffering capacity of native and dialysed boar seminal plasma and of dialysed pig blood plasma

\begin{tabular}{|c|c|c|c|c|}
\hline & 3.5 to 8 & 8 to 11 & $\begin{array}{l}\text { alues } \\
3 \cdot 5 \text { to } 11 \\
\quad(\text { total })\end{array}$ & 7 to 9 \\
\hline $\begin{array}{l}\text { Dialysed pig blood plasma ( } 3 \text { samples) } \\
\text { Mean ( } \pm \text { S.D.) mequiv. titrant } / 100 \mathrm{mg} \mathrm{N}\end{array}$ & $\begin{array}{c}0.642 \\
\pm 0.12\end{array}$ & $\begin{array}{r}0.404 \\
\pm 0.092 \\
\end{array}$ & $\begin{array}{r}1.046 \\
\pm 0.216\end{array}$ & $\begin{array}{r}0.101 \\
\pm 0.008\end{array}$ \\
\hline Mean ( \pm S.D. $) \%$ of total titrant & $\begin{array}{r}61.5 \\
\pm 0.9\end{array}$ & $\begin{array}{r}38.5 \\
\pm 0.9\end{array}$ & - & $\begin{array}{r}9 \cdot 8 \\
\pm 1 \cdot 2\end{array}$ \\
\hline $\begin{array}{l}\text { Dialysed boar seminal plasma (3 samples) } \\
\text { Mean ( } \pm \text { S.D.) mequiv. titrant } / 100 \mathrm{mg} \mathrm{N}\end{array}$ & $\begin{array}{r}0.423 \\
\pm 0.029\end{array}$ & $\begin{array}{r}0.707 \\
\pm 0.040\end{array}$ & $\begin{array}{r}1.130 \\
\pm 0.017\end{array}$ & $\begin{array}{r}0.107 \\
+0.006\end{array}$ \\
\hline Mean $( \pm$ S.D. $) \%$ of total titrant & $\begin{array}{r}37 \cdot 5 \\
\pm 2 \cdot 9\end{array}$ & $\begin{array}{r}62 \cdot 5 \\
\pm 2 \cdot 9\end{array}$ & - & $\begin{array}{r}9 \cdot 4 \\
\pm 0 \cdot 6\end{array}$ \\
\hline $\begin{array}{l}\text { Native boar seminal plasma (3 samples) } \\
\text { Mean }( \pm \text { S.D.) mequiv. titrant } / 100 \mathrm{mg} N\end{array}$ & $\begin{array}{r}1.673 \\
\pm 0.293\end{array}$ & $\begin{array}{r}1.57 \\
\pm 0.22\end{array}$ & $\begin{array}{r}3.243 \\
\pm 0.514\end{array}$ & $\begin{array}{r}0.410 \\
\pm 0.036\end{array}$ \\
\hline Mean ( \pm S.D.) $\%$ of total titrant & $\begin{array}{r}51 \cdot 5 \\
\pm 1 \cdot 0\end{array}$ & $\begin{array}{r}48 \cdot 5 \\
\pm 1 \cdot 0\end{array}$ & 二 & $\begin{array}{r}12 \cdot 8 \\
\pm 2 \cdot 2\end{array}$ \\
\hline
\end{tabular}

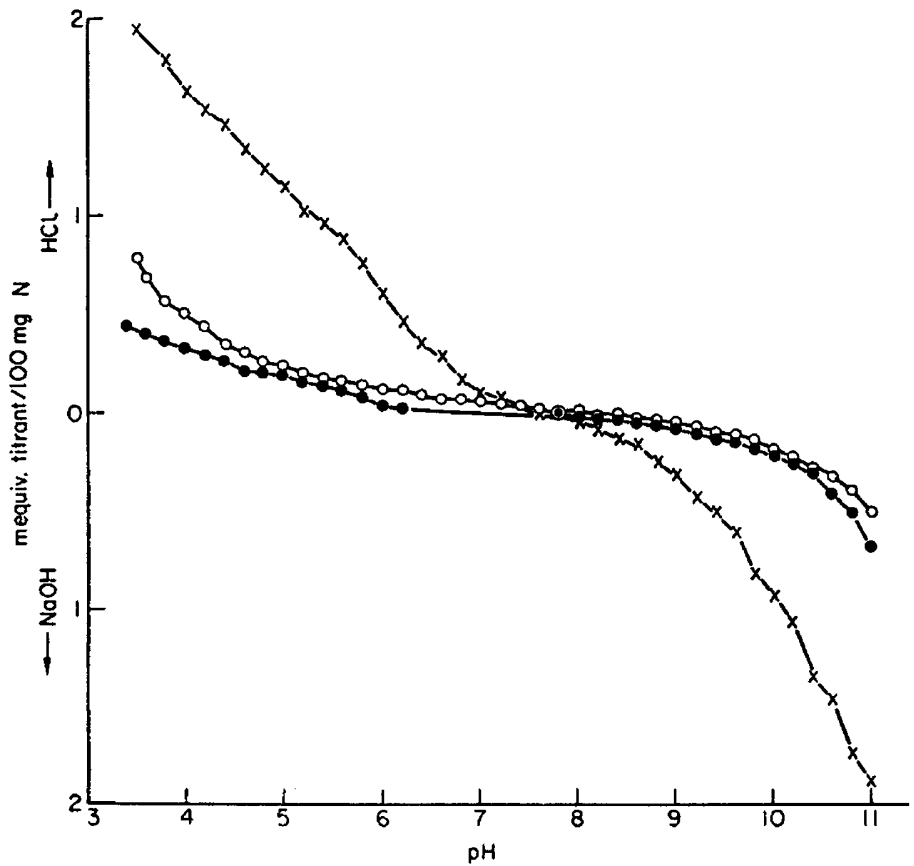

TEXT-FIG. 2. Comparison of titration curves of $(x)$ a sample of fresh boar seminal plasma (Boar $\mathrm{C}, 6 / 7 / 73)$ with $(\bullet)$ a portion of the same sample dialysed at $4^{\circ} \mathrm{C}$ against $0.2 \mathrm{M}-\mathrm{NaCl}$ adjusted to $\mathrm{pH} 7$ with a minimal quantity of tris buffer and $(0)$ a sample of pig blood plasma dialysed at $4^{\circ} \mathrm{C}$ against the same buffer. 
Buffering capacity of native and dialysed boar seminal plasma and pig blood plasma

Titrations were carried out, as described, on (1) fresh unfrozen seminal plasma, (2) samples of the same seminal plasma dialysed, and (3) dialysed samples of pig blood plasma. Table 1 gives relevant results of these experiments read from the curves (Text-fig. 2).

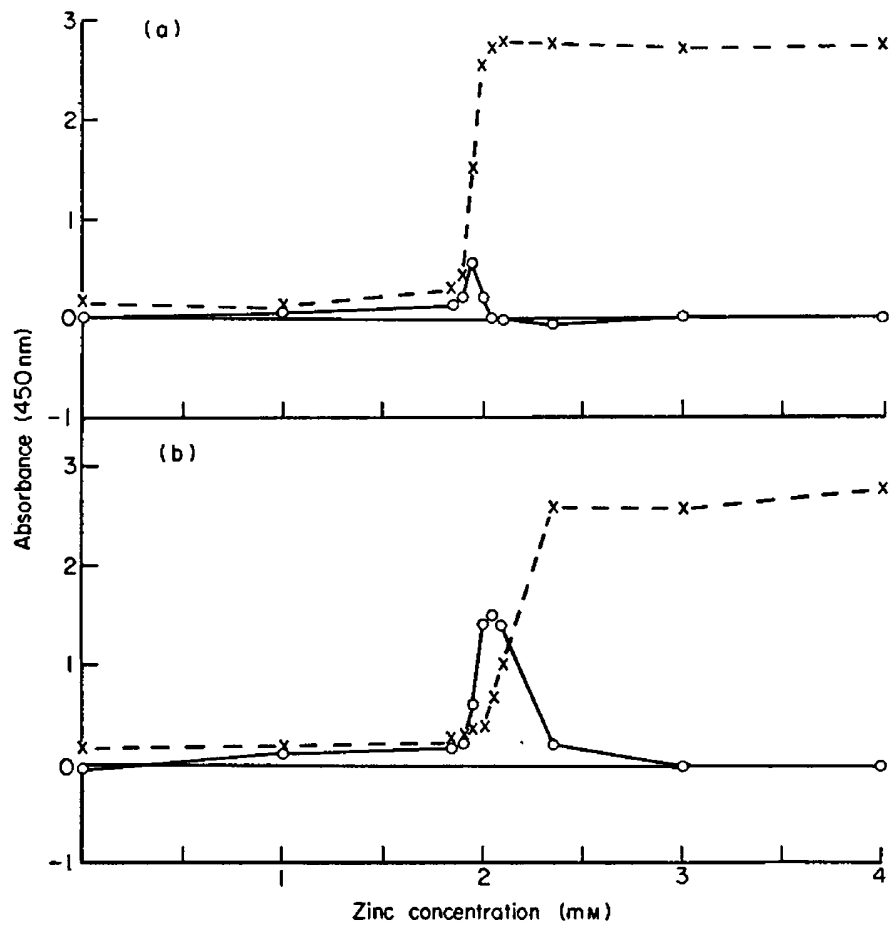

TEXT-FIG. 3. (a) Absorbance determinations on samples of crude zinc-precipitable protein, obtained from boar whole seminal plasma, in 2 mM-EDTA-tris buffer, $\mathrm{pH} 8$, after addition of zinc acetate to final concentrations shown and holding at room temperature for $2 \mathrm{hr}(x)$. The differences between these values and those given by an identical set of samples held at $4^{\circ} \mathrm{C}$ are also plotted (O). (b) Results similarly obtained with the same samples when $1 \mathrm{~mm}$-citrate was added to each.

Demonstration of cold opalescence in zinc-precipitable material obtained from boar whole seminal plasma

Aliquots $(3 \mathrm{ml})$ of this material prepared as described were kept at room temperature or at $4^{\circ} \mathrm{C}$ after the addition of graded amounts of zinc acetate ( 0 to $5 \mathrm{~mm}$ ) and adjustment to $\mathrm{pH} 8$. The mean room temperature opalescence values increased sharply at $1.90 \mathrm{~mm}$-zinc, reaching a plateau at $2.10 \mathrm{~mm}$-zinc (Text-fig. 3a). Cold opalescence was observed in the zinc concentration range 1.85 to $2.00 \mathrm{~mm}$, with a maximum at $1.95 \mathrm{~mm}$-zinc.

When, to the samples used in the above experiment, citrate was added to a final concentration of $1 \mathrm{~mm}$ and the $\mathrm{pH}$ maintained at $8 \cdot 0$, the opalescence curve at room temperature was slightly displaced (Text-fig. $3 \mathrm{~b}$ ) reaching a plateau at 2.05 mu-zinc; the cold opalescence was increased and occurred over a wider range of zinc concentrations ( 1.85 to $2.35 \mathrm{~mm}$ ). 
Identical results were obtained with the materials prepared from seminal plasma at the three different temperatures stated.

\section{Demonstration of cold-opalescence using purified zinc-precipitable protein}

Fractionation of the zinc-precipitated material from boar seminal plasma on a CM-cellulose column gave two distinct peaks. The second peak contained all the detectable ZPP. Further fractionation of this peak, using the 100 to $500 \mathrm{~mm}-\mathrm{NaCl}$ gradient, resulted in a very small peak eluting first, followed by a large peak containing ZPP. The 100 to $300 \mathrm{~mm}-\mathrm{NaCl}$ gradient enabled the latter peak to be resolved into a very small non-active peak followed by three poorly resolved large peaks all of which contained ZPP. Refractionation of the ZPP peaks on a column $(2 \mathrm{~cm} \times 100 \mathrm{~cm})$ using the same gradient gave an identical result (Text-fig. 4). The column fractions were divided into seven groups as indicated.

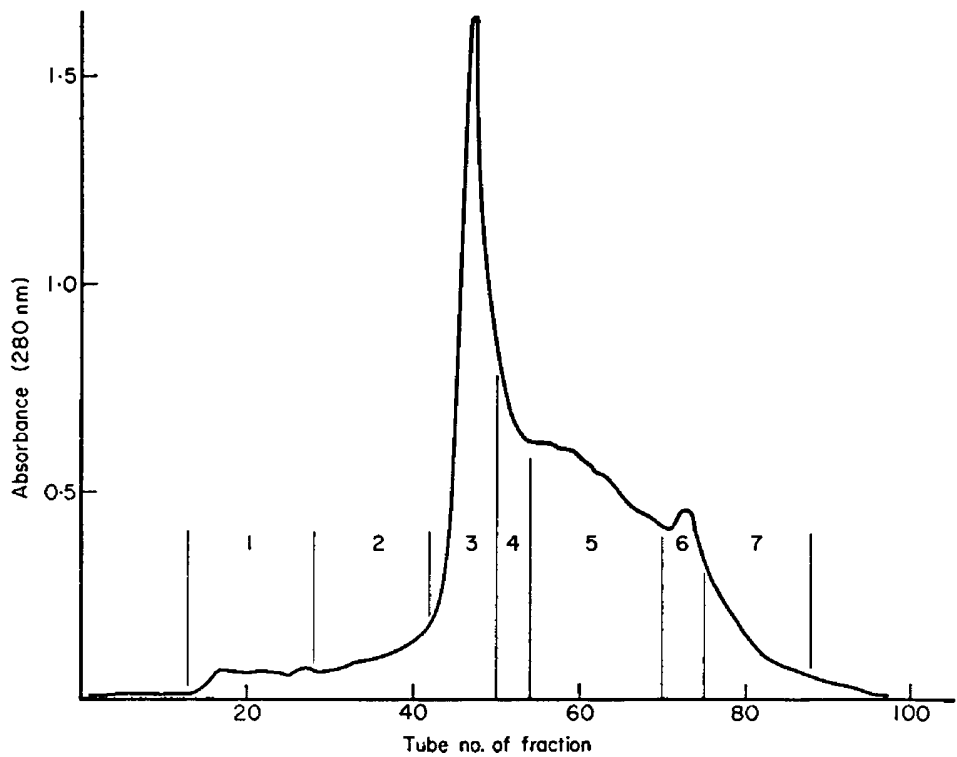

Text-Fig. 4. Absorbance of fractions obtained by elution of zinc-precipitable protein from a CM-cellulose column by using a linear gradient of 100 to $300 \mathrm{mM}-\mathrm{NaCl}$ in $2 \mathrm{~mm}$ EDTA, 20 mM-tris, pH 8.5, buffer. The added sample was obtained from boar seminal plasma after precipitation by zinc acetate followed by three successive passages through similar GM-cellulose columns at $\mathrm{pH} 8 \cdot 5$. The fractions were divided into seven groups as indicated.

Groups 1 and 2 were shown to have less than $1 \%$ of the zinc-precipitable and haemagglutinating activities eluted from the column. Each of the Groups 3 to 7 showed strong zinc-precipitable and haemagglutinating activities. Groups 3 to 7 were tested for temperature sensitivity in the presence of $1.95,2.00$ and 2.05 mM-zinc acetate after adjustment to $\mathrm{pH} 8$, and all showed increased opalescence on cooling. They were then combined and the resultant solution was used for studies on the effect of zinc concentration and $\mathrm{pH}$ on cold opalescence. 
Search for a boar seminal plasma component in CM-cellulose and G-200 Sephadex protein fractions capable of enhancing the temperature sensitivity of zinc-precipitable protein

A solution of the zinc-precipitated material from seminal plasma, fractionated on CM-cellulose at $\mathrm{pH} 8.5$ with a linear $\mathrm{NaCl}$ gradient (100 to $500 \mathrm{~mm}$ ), gave several peaks only one of which contained ZPP. Column fractions containing the protein peaks were united into groups, no tube being omitted. Equal volume mixtures of these groups with the ZPP-containing group were prepared and tested for cold opalescence at $\mathrm{pH} 8 \cdot 0$, using $1.90,2.00$ and $2 \cdot 10 \mathrm{~mm}$-zinc concentrations. In five fractionation experiments, none of the mixtures gave greater cold-opalescence than was observed with the ZPP-containing group alone.

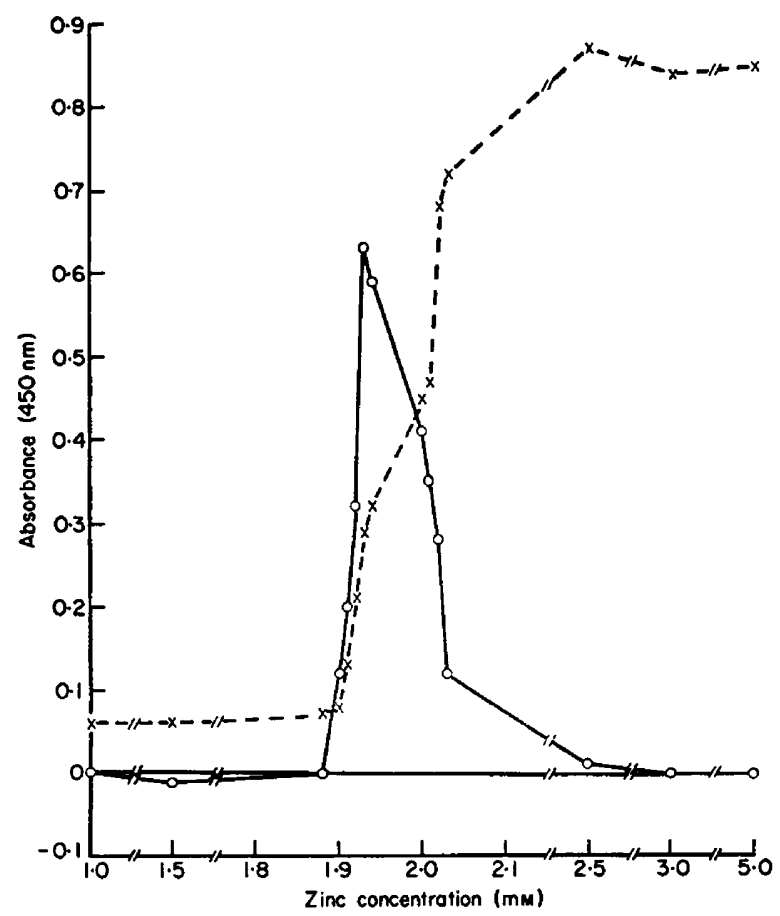

TEXT-FIG. 5. Absorbance determinations on aliquots of purified zinc-precipitable protein (obtained from boar seminal plasma) in $2 \mathrm{~mm}$-EDTA, $20 \mathrm{~mm}$-tris buffer, $\mathrm{pH} 8$, each aliquot containing increasing concentrations of zinc acetate as shown. Values after $2 \mathrm{hr}$ at room temperature $(x)$. The differences between these values and those given by an identical set of samples held at $4^{\circ} \mathrm{G}$ for $2 \mathrm{hr}$ are also plotted $(0)$.

Seminal plasma or the zinc precipitate were subjected to gel-filtration at $\mathrm{pH} 4$ on G-200 Sephadex. No enhancement of the cold opalescence was seen following addition of other groups from the column to the ZPP-containing group.

\section{Effect of zinc level and $p H$ on cold opalescence of purified zinc-precipitable protein}

Considerable cold opalescence in the zinc range 1.90 to $2.15 \mathrm{~mm}$ could be demonstrated in the stock purified ZPP solution, when tested at $\mathrm{pH} \mathrm{8.0}$ (Text-fig. 5). In concentrations greater than $2.15 \mathrm{~mm}$, the zinc ions induced 
precipitation of the protein at room temperature but with no significant increase in precipitation on cooling.

Experiments were then carried out to determine the $\mathrm{pH}$ range over which the low $(1.90$ to $2.10 \mathrm{~mm})$ levels of zinc would induce cold opalescence. Tests were carried out on samples from $\mathrm{pH} 6.0$ to $\mathrm{pH}$ 9.5. Significant cold opalescence was only observed in these aliquots at final $\mathrm{pH}$ values between $7 \cdot 3$ and $8 \cdot 5$. There was a quantitatively larger increase in the opalescence on cooling in the samples between $\mathrm{pH} 7.40$ and 8.30 with a maximum at $\mathrm{pH} 7.7$ (Text-fig. 6a).

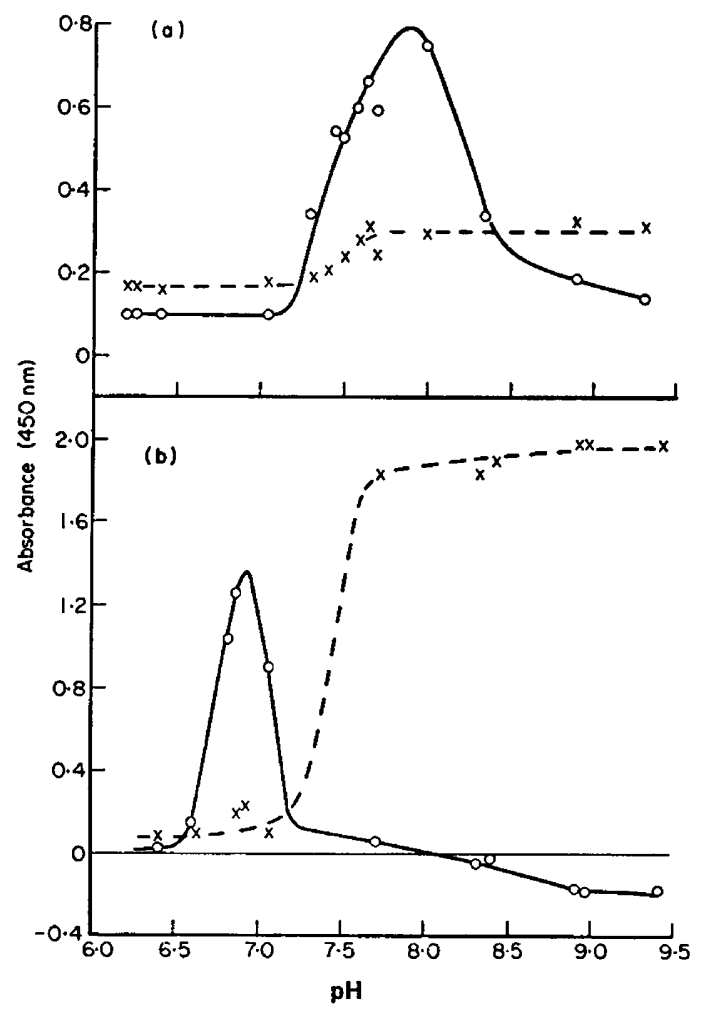

TEXT-FIG. 6. Representative experiments on boar seminal plasma giving absorbance determinations of aliquots of purified stock zinc-precipitable protein (ZPP) (which contained added 2.0 mM-EDTA) after adjustment to the pH values shown. $\times$, Values after $2 \mathrm{hr}$ at room temperature; $O$, cold opalescence values (difference between those at $4^{\circ} \mathrm{C}$ and those at room temperature). (a) With 1.90 to $2.10 \mathrm{~mm}$-added zinc; (b) with $5 \mathrm{mM}$-added zinc. The ZPP concentration in (b) was twice that in (a).

When similar tests were carried out in the presence of $5 \mathrm{~mm}$-zinc ions, temperature sensitivity was only observed in those aliquots at $\mathrm{pH} 6.8$ and 7.2 (Text-fig. 6b). It will be seen, in the samples at $\mathrm{pH} 7 \cdot 3$ to $9 \cdot 4$, that a maximum opalescence occurred on addition of the zinc at room temperature. This did not increase on cooling. The opalescence at room temperature of those samples below $\mathrm{pH} 7.3$ was always very low, but the increase on cooling was quantitatively similar to that observed with the low zinc between $\mathrm{pH} 7 \cdot 40$ and $8 \cdot 30$. 


\section{DISCUSSION}

In earlier work on the causes of opalescence in boar seminal plasma (Boursnell \& Roberts, 1974; Roberts et al., 1974), considerable variations between samples were encountered, both in the initial opalescence values and in the subsequent increase due to cooling. A search for the cause of these variations suggested that $\mathrm{pH}$ changes of fresh samples of seminal plasma could be a contributory factor. The range of protein, zinc and citrate concentrations shown by Boursnell, Baronos, Briggs \& Butler (1972) may also contribute to the factors causing variations in cold opalescence between one sample of seminal plasma and another. Hancock (1959) showed that boar semen exhibited a marked increase $\left(0.5 \mathrm{pH}\right.$ unit) in $\mathrm{pH}$ when it was exposed to air for $4 \mathrm{hr}$ at $37^{\circ} \mathrm{C}$ and that the increase was much less when identical samples were retained in closed vessels. This change of $\mathrm{pH}$ was attributed to loss of $\mathrm{CO}_{2}$. In the work reported in this paper, the $\mathrm{pH}$ change of small samples $(3 \mathrm{ml})$ of seminal plasma kept at room temperature for only $2 \mathrm{hr}$ in open cuvettes was often much greater (about $1 \mathrm{pH}$ unit) than that reported by Hancock (1959) for whole semen collections. The reason for this considerable sensitivity of boar seminal plasma, attributed to $\mathrm{CO}_{2}$ loss, was investigated.

Studies on the titration characteristics of dialysed seminal plasma proteins revealed that, compared to dialysed blood plasma proteins, there was a considerably greater percentage of residues titrating from $\mathrm{pH} 8$ to 11 than from pH 3.5 to 8. This accords with the previous findings (Boursnell \& Briggs, 1969; Lavon \& Boursnell, 1971) that the majority of the seminal plasma proteins are notably basic.

As with the majority of proteins (Herriott et al., 1947; Tanford, 1950), there is a paucity of radicals titrating between $\mathrm{pH} 7$ and 9 . This lack of buffering capacity in the physiological range ( $\mathrm{pH} 7$ to 9) also applies to whole seminal plasma. Relatively, it differs little from that of the dialysed material $(11.0 \%$ and $9.9 \%$, respectively, of the mequiv. of titrant required throughout the range $\mathrm{pH} 3 \cdot 5$ to 11 ).

In the present study, the cold opalescence observed in samples of seminal plasma was seen to vary markedly with $\mathrm{pH}$. The maximum cold opalescence in seminal plasma was observed at $\mathrm{pH} 8.0$ to $8 \cdot 5$. This may explain why Boursnell, Nelson \& Cole (1966) observed cold opalescence only in some samples of boar seminal plasma which had been frozen. The results of three experiments showing the variations in overall absorbance values encountered between seminal plasma samples are shown in Text-fig. 1. The reasons for these variations are not known.

The preliminary investigations of Roberts et al. (1974) on the nature of the cold opalescence led them to suggest the possibility of the existence of a temperature-sensitive factor in boar seminal plasma that combined with ZPP and zinc to give rise to cold opalescence, since the purified ZPP prepared by column chromatography apparently was not itself temperature-sensitive. In the present work, this suggestion has been further investigated and studies with the purified ZPP showed that its temperature-sensitivity was indeed dependent upon very low and critical concentrations of zinc ions in the $\mathrm{pH}$ range 7.3 to 
about 8.5 (Text-fig. 6a). In the previous study, where increments of more than $0.5 \mathrm{~mm}$-zinc were employed, the necessity of these low concentrations was not understood.

The observation that a separate temperature-sensitive factor appeared to be unnecessary is supported by the finding that cold opalescence could be observed in all the zinc-precipitable seminal plasma fractions prepared at $37^{\circ} \mathrm{C}$, room temperature and at $4^{\circ} \mathrm{C}$. Moreover, gel filtration fractionation of seminal plasma showed that the ZPP-containing region (Boursnell \& Roberts, 1974) could be made to demonstrate cold opalescence under the above conditions. This was not enhanced by mixing with groups from any other region of the fractionation pattern.

From observations on the effect of citrate on the cold opalescence observed with seminal plasma fractions (Text-fig. 3b), it would seem possible that in whole seminal plasma other factors, chemical and physico-chemical, may affect the interactions of ZPP and the indigenous zinc. The action of some of these factors may be reflected in the wider range of added zinc concentrations $(0$ to 2 $\mathrm{mm}$ ) capable of inducing cold opalescence in whole seminal plasma (Roberts et al., 1974). These factors may moderate the reaction by competively complexing the available zinc or ZPP. Two illustrations of this possibility may be cited. The crude ZPP prepared from seminal plasma contains small quantities of protein material which separate even after four passages through CM-cellulose, but this might represent instability of the proteins under the experimental conditions used. It is possible that the high concentration of citrate (mean 6.6 $\mathrm{mm}$; Boursnell et al., 1972) present in seminal plasma is involved. Roberts et al. (1974) have shown by ultrafiltration that, on a molar basis much more citrate than zinc ( 9.6 times) is bound to high molecular weight material, presumably protein, when seminal plasma samples are cooled to $4^{\circ} \mathrm{C}$. This may well, as they state, affect the behaviour of the proteins on cooling.

When considering the zinc concentrations used in the present study, note should be taken of the 2 mM-EDTA present in the buffer. This was routinely introduced in order to eliminate the possibility of deleterious consequences of the introduction of trace metal contamination from glassware or reagents. Boursnell \& Roberts (1974) showed that zinc is chelated by EDTA in preference to ZPP, and that there is apparently a stoichiometrical relationship between the EDTA and zinc present in seminal plasma. Thus, the actual concentration of zinc available to the ZPP is determined by the exact concentration of EDTA present. The fact that the concentrations of zinc which induced opalescence varied slightly around $2 \mathrm{~mm}$ was due presumably to the slight metal contamination mentioned above, which would effectively lower the binding capacity of the EDTA for the added zinc. In our past researches involving the trace metal zinc, we have found that contamination from washed glassware and other sources is rarely, if ever, greater than $0 \cdot 1$ part $\mathrm{Zn} / 10^{6}$ (approx. 0.013 mm).

Although the occurrence of cold opalescence on the scale exhibited by boar seminal plasma has not been observed in the seminal plasma of other species, it is interesting to note that fractionation of human seminal plasma has shown the association of zinc with high molecular weight protein (Eliasson \& Lindholmer, 
1971). The relationship of this material to the zinc-sensitive boar seminal protein is unknown at present.

\section{ACKNOWLEDGMENTS}

We are grateful to Mr A. D. Brown for his help with some of the experiments reported in this paper, and to Miss Wendy Butler for so readily arranging the many collections of samples used.

We would like to express our thanks to the Royal College of Veterinary Surgeons Trust Fund for a grant which helped to defray the expenses of this work and, in particular, for the award to one of us (T.K.R.) of a Senior Fellowship in Animal Health.

\section{REFERENCES}

Boursnell, J. C. (1967) Boar seminal haemagglutinin. II. Combination with red cells and spermatozoa. 7. Reprod. Fert. 13, 297.

Boursnell, J. G., Baronos, S., Briggs, P. A. \& Butler, E. J. (1972) The concentrations of zinc in boar seminal plasma and vesicular secretion in relation to those of nitrogenous substances, citrate, galactose and fructose. F. Reprod. Fert. 29, 215.

Boursnel. , J. C. \& Briggs, P. A. (1969) Boar seminal plasma proteins. 2. Electrophoretic identification of the haemagglutinin. $\mathcal{F}$. Reprod. Fert. 19, 157.

Boursnell, J. G. \& Coombs, R. R. A. (1966) A haemagglutinating factor in boar seminal plasma. F. Reprod. Fert. 11, 139.

Boursnell, J. G., Hartree, E. F. \& Briggs, P. A. (1970) Studies of the bulbo-urethral (Cowper's)gland mucin and seminal gel of the boar. Biochem. F. 117, 981 .

Boursnell, J. G., Nelson, M. \& Cole, D. M. (1966) Studies on boar seminal plasma proteins. 3. Fractionation by gel filtration, ion exchange and other means. Biochim. biophys. Acta, 117, 134.

Boursnele, J. C. \& Roberts, T. K. (1974) The rôle of zinc in promoting the opalescence and coldprecipitation of boar seminal plasma. 7. Reprod. Fert. 36, 91 .

Eliasson, R. \& Lindholmer, G. (1971) Zinc in human seminal plasma. Andrologie, 3, 147.

Hancock, J. L. (1959) Semen and testis characteristics and sexual behaviour of boars. F. agric. Sci., Camb. 53, 313.

Herriott, R. M., Anson, M. L. \& Northrop, J. H. (1947) Reaction of enzymes and proteins with mustard gas (bis ( $\beta$-chloroethyl) sulfide). F. gen. Physiol. 30, 185.

LAVON, U. \& BoursNelL, J. C. (1971) Characterization of boar seminal plasma, vesicular secretion and epididymal plasma proteins by gel disc electrophoresis and isoelectric focusing on polyacrylamide. 7. Reprod. Fert. 27, 227.

Miller, G. L. \& Golder, R. H. (1950) Buffers of pH 2 to 12 for use in electrophoresis. Archs Biochem. $29,420$.

RoberTs, T. K., Boursnell, J. G. \& BROWN, A. D. (1974) The rôle of zinc in promoting the opalescence and cold precipitation of boar seminal plasma. II. Relationship of a zinc-precipitable protein with the haemagglutinin. 7 . Reprod. Fert. 37, 373.

TANFord, G. (1950) Preparation and properties of serum and plasma proteins. 23. Hydrogen ion equilibria in native and modified human serum albumins. F. Am. chem. Soc. 72, 441. 